\title{
Pathways out of poverty through the lens of development resilience: an agent-based simulation
}

\author{
Yue Dou $^{1}, \underline{\text { Peter J. Deadman }}^{2}$, Marta Berbés-Blázquez $^{3}$, Nathan D. Vogt $^{4}$ and Oriana Almeida $^{5}$
}

\begin{abstract}
Poverty alleviation for smallholders must consider the increasingly varied and intertwined impacts of climate change and globalization. This calls for a resilience perspective that includes eradication of poverty and resilience enhancement under extreme events and shocks. Applying the framework of development resilience, we constructed an agent-based model based on small farming households in the Amazon Delta region in Brazil, and we used it to identify pathways out of poverty and sources for resilience among these households. The model allows us to explore the nonlinearity and heterogeneous nature of the smallholder livelihood systems, including how different household characteristics and livelihood strategies contribute to divergent livelihood outcomes. Using a unique yet simple tracking method, we were able to show the stochastic dynamics of individual household livelihoods in the face of various shocks, and how these households move in and out of different states of poverty over time (i.e., extremely poor, chronic poor, and nonpoor). By comparing traits of households that ended up in different states, we showed the need for targeted interventions for alternative livelihood strategies and key resources improvement. Different from conventional poverty alleviation programs, our findings emphasize empowering smallholders with different livelihood options. This has practical implications in terms of identifying leverage points in smallholder livelihood systems (e.g., livelihood strategy, land resources) that government and other agencies can use to intervene more effectively for households to become prosperous.
\end{abstract}

Key Words: agent-based model; development resilience; livelihood; poverty; poverty trap; smallholder

\section{INTRODUCTION}

Rural dwellers account for $75 \%$ of the world's poor and foodinsecure people. They are disproportionately affected by environmental and socioeconomic changes, given their limited coping capacity and low profit margins (Carter et al. 2007). Policymakers, nonprofit organizations, and scholars continue to grapple with the compounded impacts that climate change, environmental degradation, political instability, disease, and economic uncertainty pose to poverty alleviation. These increasing, varied, and intertwined challenges faced by the rural poor have led to a greater focus on resilience thinking as a new conceptual and analytical perspective to alleviate the poverty of smallholders and inform poverty reduction practices in rural contexts (Folke et al. 2002, 2010, Coppock et al. 2011, Hanazaki et al. 2013, Barrett and Constas 2014). An important approach that has arisen from this work is the concept of development resilience (Barrett and Constas 2014, Nayak et al. 2014, Tanner et al. 2015).

Development resilience is defined as "the capacity over time of a person, household or other aggregate unit to avoid poverty in the face of various stressors and in the wake of myriad shocks" (Barrett and Constas 2014:14626). Drawing from ecological and poverty studies, development resilience provides a system's view of poverty that incorporates temporal changes in livelihoods and accounts for the nonlinear and uncertain nature of poverty. Development resilience considers how households (or other units of analysis) move between three alternative states: the humanitarian emergency state (i.e., death among individuals or a community if no immediate assistance is provided), the chronic poor state (i.e., a poor standard of living), and a nonpoor state (i.e., a favorable, good standard of living; Barrett and Constas 2014). Development resilience draws heavily on previous concepts of resilience (e.g., Holling 1973, Walker et al. 2004, and Grafton et al. 2019). However, it is a normative term, that is, more is better, which is different from other views of resilience as a characteristic of a system. In development resilience, if a household has the capacity to avoid poverty over time, this household is resilient. Development resilience can also be applied at either the individual level (e.g., households) or an aggregated level (e.g., communities). This allows us to explore household heterogeneity in which some households may need more assistance than others, thus providing a framework for empirically evaluating resilience of heterogeneous households or communities.

A good outcome of development resilience is when formerly poor households move to a nonpoor state and stay there despite shocks to their livelihoods. Therefore, this study aims to identify leverage points in the smallholder livelihood system that are crucial for smallholders to escape poverty. Specifically, we undertook two tasks to fulfill this goal: (1) reveal "pathways out of poverty," which we define as upward livelihood trajectories in which households will reach the nonpoor zone regardless of shocks. Among all possible livelihood trajectories, we eliminate downward trajectories and identify those within which smallholders are expected to recover from shocks. (2) Uncover what might be sources of resilience in households that follow these pathways to inform policy interventions and programs designed to help smallholder households out of poverty.

A variety of modeling approaches have been deployed to detect and understand poverty, such as linking remote sensing and machine learning (Blumenstock et al. 2015, Jean et al. 2016,

\footnotetext{
${ }^{1}$ Environmental Geography Group, Institute for Environmental Studies (IVM), Vrije Universiteit Amsterdam, Amsterdam, The Netherlands, ${ }^{2}$ Department of Geography and Environmental Management, University of Waterloo, Waterloo, Ontario, Canada, ${ }^{3}$ Arizona State University, School for the Future of Innovation in Society, Tempe, Arizona, USA, ${ }^{4}$ University of Paraíba Valley, São José dos Campos, São Paulo, Brazil, ${ }^{5}$ Núcleo de Altos Estudos Amazônicos da Universidade Federal do Pará, Pará, Brazil
} 
Watmough et al. 2019), and statistical models (Carter et al. 2007, Cinner et al. 2011, Thomas and Gaspart 2015). These methods are important and have contributed to identifying factors influencing poverty for policy interventions, however, they may not be able to capture the nonlinearity of livelihood trajectories, or fail to factor how household heterogeneity and decision making lead to alternative outcomes (Thomas and Gaspart 2015, Grêt-Regamey et al. 2019). Systems simulation tools, which allow researchers to uncover the underlying relationships and complexities of smallholder livelihood systems, are needed to better understand the failures or successes of poverty-alleviation interventions and quantify the effects of household heterogeneity.

Agent-based modeling (ABM) is an approach that represents a collection of human decision makers as agents that interact with each other and their environment over time. It is a widely used tool for exploring the dynamics of coupled human and natural systems including land use and land-cover change, conservation policies, forest policy, and carbon storage change (Liu et al. 2007, An 2012, Rounsevell et al. 2012, Huang et al. 2013, Huber et al. 2018). However, few ABMs have explored poverty and livelihood dynamics (Smajgl 2013, Wossen 2015) within a resilience perspective. Here, an ABM was developed to represent the livelihood dynamics of smallholder rural populations and was used to explore the concept of development resilience at the household level. We defined livelihoods to be composed of the assets, capabilities, and activities required for a means of living (Chambers and Conway 1991). The model was implemented to represent the smallholders (i.e., Caboclos) in the Brazilian Amazon Delta region as an example. The livelihoods of Caboclos have been marked by extreme climatic hazards and market oscillations in past decades (Pinho et al. 2015, Brondízio et al. 2016, Vogt et al. 2016), resulting in an urgent need to improve their development resilience. Within our ABM, an agent is a household and an agent's livelihood is influenced by the decisions that the agent makes (i.e., its livelihood strategy) in response to the social, economic, or environmental inputs received from the world in which they exist.

The model that we constructed captures the heterogeneity of smallholder systems, including the heterogeneous characteristics and the different livelihood strategies, which lead to various livelihood outcomes. Using the simulation results, we adopted statistical methods to identify critical characteristics and strategies of households resulting in different livelihood trajectories. These constitute leverage points that can shift smallholders out of poverty. The flexibility embedded in ABM enables us to explore the complexity of smallholder systems, and thereby reveal underlying sources and mechanisms for pathways through which smallholders can enhance resilience and stay out of poverty. Using findings from this study, we recommended twofold interventions and policy implications that aim to enhance development resilience, including elevating current poor households from less desirable situations and helping households stay in favorable states.

\section{MODELING THE SMALLHOLDER SYSTEM}

An agent-based model was developed to represent smallholder livelihood systems in the Amazon Delta region. Smallholder livelihood systems refer to a coupled human-natural system where people's livelihoods are directly tied to their natural resource utilization, such as small-scale agriculture and agroforestry. This model is informed by data obtained from Caboclos communities in the Amazon Delta region and captures household demography and assets (e.g., capital, land ownership), households' choices of cash crop, subsistence activities, and crop suitability in upland and floodplain regions. Because poverty and increasing shocks are the critical issues in this region, the ABM gives special consideration to the baseline and shock simulations and the analyses of livelihood outcomes using the development resilience framework.

\section{Description of the study site}

This case study focuses on the Caboclos communities in the municipality of Abaetetuba in the state of Pará, Brazil. The per capita gross domestic product (GDP) of the state of Pará is $52 \%$ of the national average and its human development index ranked $24^{\text {th }}$ among the 27 Brazilian states in 2010. It is an important case to explore in terms of development resilience because of the frequent and intense shocks that the Caboclos have faced. For example, although the Caboclos have lived in a highly dynamic environment with tidal floods for centuries, climate change is causing more severe droughts and floods in recent decades (Pinho et al. 2015, Brondízio et al. 2016). In addition, there have been drastic boom and bust cycles of mango and rubber in this region during early the 20th century, whereas in recent decades the açaí fruit has experienced a boom in popularity in the national and global markets (Brondízio 2008) and the Caboclos manage this fruit as a cash crop.

Traditionally, the Caboclos used a variety of resources and livelihood activities that included shifting cultivation, palm fruit/ wood/oil extraction, fishing and shrimping, and cash crops, such as rubber, mango, or cacao (Fig. 1). Today, açaí is one of the top sources of income for the majority of Caboclos (Brondízio 2004, Dou et al. 2017). Increased global demand for açaí means that the Caboclos have intensified and increased açaí production for cash revenue, even expanding its cultivation to the uplands where soil conditions are less suitable than the floodplain. Consequently, agricultural production of staples such as manioc flour and rice has decreased, to the point that farmers purchase these food items from the regional market. Abaetetuba is the second-largest producer of açaí in Pará and over $90 \%$ of households are engaged to some degree of açaí production (Brondízio 2008). The increasing market demand for açaí has brought substantial economic benefits for Caboclos. However, the consequences in terms of livelihood and ecosystem resilience are unclear (Vogt et al. 2016, Dou et al. 2017), especially when the experience from other superfoods, such as quinoa, is not without negative consequences for farmers (Jacobsen 2011).

\section{Model representation}

The model used is a revised version of MARIA (Cabrera et al. 2010), which is written in Java using the RePast multiagent simulation platform (http://repast.sourceforge.net/). Compared to the original version of MARIA, the agents' decision-making algorithm has been expanded to cover three different livelihood strategies with respect to calibrated employment probability; and the environmental module incorporates the different crop suitability in upland and floodplain. A brief description of the model is provided here (Table 1). The ODD description of the 
model and the code are available at CoMSES/OpenABM website: https://www.comses.net/codebases/8aa00021-e4d3-4468aa6d-f6c474e459e0/releases/1.0.0/

Fig. 1. Caboclos and their house, açaí, and upland. (a) Caboclos live in wooden houses that are built on the floodplain. The water level fluctuates hourly and the high tides sometimes reach the floor of their houses. The extreme high tides are called lancentes, and have been observed with increasing frequency and duration over the past three decades. Caboclos also manage the forest around their houses intensively. The house garden usually contains açaí trees and some other fruit trees (e.g., lemon, papaya, and banana). (b) Caboclos sell açaí in the market. Açaí was only consumed within the household, but now is a popular commodity and reliable source for family revenue. (c) Caboclos also manage the upland to grow manioc and other crops.

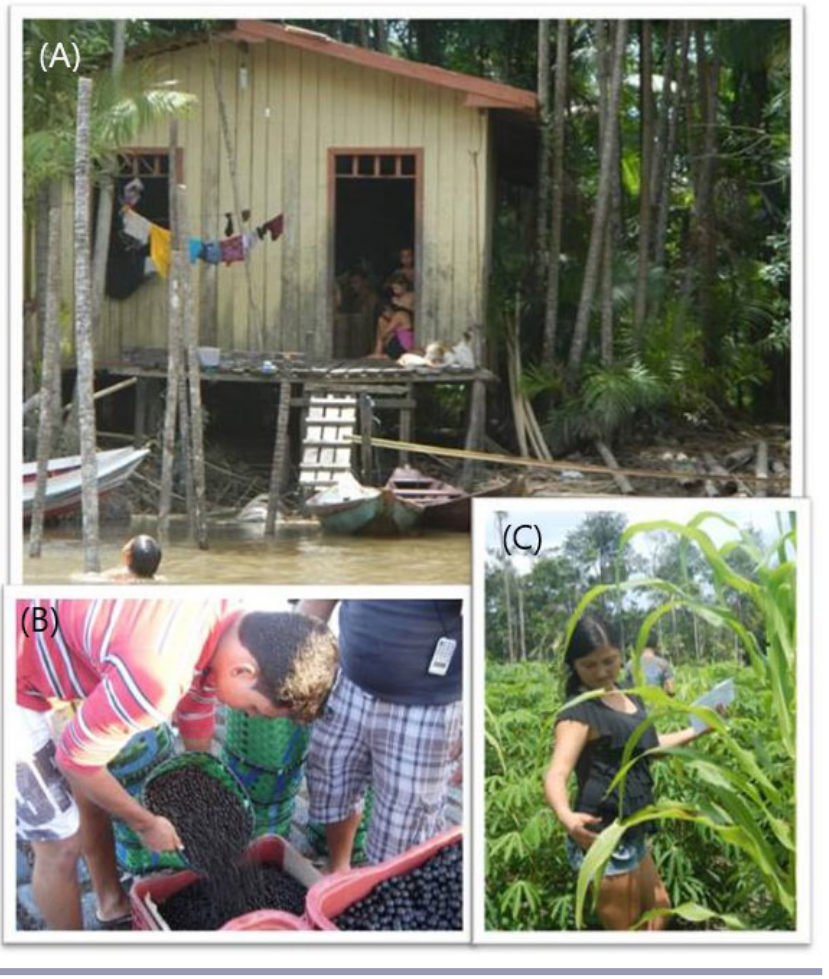

Agents

Each agent in the simulation represents a household that is described by a set of demographic attributes (e.g., number of family members, age of family member) and several production resources (e.g., land property, initial capital). These characteristics are updated every year of the simulation. The demographic composition determines the available labor of the family, which affects how agents interact with the environment. The available labor is calculated by converting family members' age and gender into a labor unit (Table 1). Labor is one input in the agent's land use decision making, which includes deforestation and the conversion of land cells to crop such as açaí. Other key variables and their definitions are listed in Table 1. For a complete list of variables please refer to CoMSES/ OpenABM.

\section{Environment}

Within the environmental module, households interact with a raster landscape containing water and land cells that are $15 \mathrm{~m} \times$ $15 \mathrm{~m}$ rectangle grids classified from remote sensing images. Land cells evolve with land-use history and land-cover transition rules. They can be cultivated by agents to grow açaí, agriculture, or stay as forest. The rules of land-cover transition and feedbacks are derived from previous research in this region (Brondízio 2008) and summarized as follows (Table 1): first, the crop cultivation history affects the soil fertility and crop yield in return. For example, the fertility is coded as an indicator from 0 to 1 and changed by a threshold corresponding to the crop cultivated and a random number every year. For annual crops, after two to three years the fertility indicator drops to zero. This represents the need for shifting cultivation. For açaí as agroforestry, this indicator drops from 1 to 0 after 10 years. The fertility returns to 1 when land is fallowed for 10 years. Second, the distance to houses and water has an impact on the agent's land-use decisions. For example, land cells close to houses are more likely to be developed than land cells further away. In addition, land cells on the floodplain have a higher açaí yield than upland cells, and the reverse for the yield of manioc

\section{Livelihood strategies}

A fuller description of the agents' livelihood strategies is provided in the ODD file on the CoMSES/OpenABM website. Agents in the model follow one of three strategies when making decisions regarding the allocation of resources to different livelihoodgenerating activities. Based on our field studies (Vogt et al. 2016, Dou et al. 2017), collective expertise, and existing ABM examples, the following three livelihood strategies were examined. All households followed the same livelihood strategy throughout a single simulation. The three livelihood strategies were simulated for every scenario respectively.

"Just Enough" (JE) is based on Chayanov's theory of peasant labor that notes how farmers make decisions to fulfill two opposing objectives: an income objective that requires labor input, and a work-avoidance objective that conflicts with income generation (Chayanov 1966, Ellis 1994). In this strategy, traditional households do not operate as enterprises, and their utility is not solely derived from profit, hence they will stop working once their subsistence requirements are met.

"Maximizing Profit" or "Max Profit" (MP) is based on economic optimization that prioritizes monetary returns to all factors of production (Barlett 1984, Colman and Young 1989). In this strategy, households seek the highest possible net income according to market prices. Unlike traditional farmers, this strategy considers farm households similar to enterprises that seek the highest revenue. In our model, the main crops are açai and manioc, whereby the market price of açaí has been substantial for the past 30 years and the price of manioc has been relatively low. Therefore, most households allocate all their resources to grow açaí and purchase manioc from the market. Households use the average price and yield from the past three years to make landuse decisions for the coming year (Brondízio and Moran 2008).

The "Subsistence First" (SF) strategy is based on rules and heuristic decisions that have been observed in the field and implemented in ABMs (Barlett 1984, Mccracken et al. 2002, VanWey et al. 2007). For example, farming households make 
Table 1. Representing the smallholder system using an agent-based model.

\begin{tabular}{|c|c|c|c|c|}
\hline & Real World & Model Representation & Sample Variables & Description \\
\hline Human & $\begin{array}{l}\text { Farming households with a } \\
\text { mixed generation of members, } \\
\text { in possession of land and } \\
\text { other assets, adopting unique } \\
\text { livelihood strategy }\end{array}$ & $\begin{array}{l}\text { Agents with a list of family } \\
\text { members that are different in } \\
\text { age, gender, and education; } \\
\text { each agent has capital and } \\
\text { land assets from an empirically } \\
\text { tuned distribution, associating } \\
\text { with one livelihood strategy }\end{array}$ & $\begin{array}{l}\text { aveFemaleEdu } \\
\text { husEdu } \\
\text { age } \\
\text { capital }\end{array}$ & $\begin{array}{l}\text { average schooling years of all female members in the } \\
\text { family } \\
\text { the schooling years of the husband (household head) in } \\
\text { the family } \\
\text { every family member has an age profile and updates every } \\
\text { year } \\
\text { total monetary possession, update every tick (year) by } \\
\text { adding the annual profit of growing crops, off-farm salary, } \\
\text { government cash transfer, and subtracting the subsistence } \\
\text { requirement and cultivation costs } \\
\text { total available labor unit, including family members who } \\
\text { are in working condition (excluding elders, kids, and off- } \\
\text { farm worker) and is converted to a labor unit, update } \\
\text { every year } \\
\text { qualified elders will receive government pension, update } \\
\text { every year } \\
\text { the salary this family receives if any family member works } \\
\text { an off-farm job } \\
\text { the monetary unit by adding up every family member's } \\
\text { food demand }\end{array}$ \\
\hline Environment & $\begin{array}{l}\text { Floodplain (Várzea): land } \\
\text { covered by tidal floods is } \\
\text { suitable for growing açaí } \\
\text { berries; manioc will have } \\
\text { substantially lower yield on } \\
\text { floodplain. } \\
\text { Upland: land that can be used } \\
\text { to grow annual crops such as } \\
\text { manioc; açaí will have } \\
\text { substantially lower yield on } \\
\text { upland } \\
\text { Both land types can be } \\
\text { affected by abnormal tides }\end{array}$ & $\begin{array}{l}\text { A binary grid indicates water } \\
\text { and land; land is divided into } \\
\text { floodplain and upland by the } \\
\text { distance to water }\end{array}$ & $\begin{array}{l}\text { isUpland } \\
\text { yearDeforested } \\
\text { disToWater } \\
\text { fertility }\end{array}$ & $\begin{array}{l}\text { boolean, indicating this land cell is in floodplain or } \\
\text { upland, which will affect the range of crop yield } \\
\text { which year this land cell is deforested } \\
\text { distance to the water area } \\
\text { represents the soil fertility of the land cell, which is } \\
\text { affected by the deforestation year and cultivation history }\end{array}$ \\
\hline $\begin{array}{l}\text { Human- } \\
\text { environment } \\
\text { interactions }\end{array}$ & $\begin{array}{l}\text { Farmers can grow annual } \\
\text { crops, agroforestry, and go } \\
\text { fishing, shrimping, as well as } \\
\text { working in the nearby town to } \\
\text { gain a salary }\end{array}$ & $\begin{array}{l}\text { To simplify, model represents } \\
\text { growing annual crops (manioc) } \\
\text { and agro-forestry (açaí), and } \\
\text { working off-farm in the nearby } \\
\text { town; } \\
\text { Each land cell grid has its own } \\
\text { biophysical attributes, which } \\
\text { affect crop yields. These } \\
\text { attributes can be changed by } \\
\text { human land use to some } \\
\text { degree }\end{array}$ & $\begin{array}{c}\text { açaí } \\
\text { maniocgarden } \\
\text { forest } \\
\text { fallow } \\
\text { other } \\
\text { Yield }_{\text {Crop }} \\
\text { probOffFarmJob }\end{array}$ & $\begin{array}{l}\text { land cells that are used to cultivate açaí } \\
\text { land cells used to cultivate manioc } \\
\text { land cells remain forest } \\
\text { land cells under fallow } \\
\text { land cells for other crops } \\
\text { yield for a certain crop on this cell is determined by soil } \\
\text { fertility, climate indicator, and distance to water, with a } \\
\text { random effect generator } \\
\text { calculated based on market condition and a probability } \\
\text { function of family characteristics that include } \\
\text { aveFemaleEdu, husEdu, age }\end{array}$ \\
\hline Potential shocks & $\begin{array}{l}\text { Açaí price bust: similar as the } \\
\text { previous boom-bust cycles for } \\
\text { other commodities, the } \\
\text { popularity of açaí in } \\
\text { international market may go } \\
\text { down or new cultivation } \\
\text { technology being developed so } \\
\text { floodplain loses its unique } \\
\text { suitability } \\
\text { Climatic hazards: lancentes, } \\
\text { the extreme regional tidal } \\
\text { floods, affect crop yield } \\
\text { Social instability: the change } \\
\text { of political system may affect } \\
\text { the policy implementation and } \\
\text { societal development }\end{array}$ & $\begin{array}{l}\text { The variables that represent } \\
\text { açai price, climate event (that } \\
\text { controls the yield), and job } \\
\text { opportunities drop the value } \\
\text { by } 90 \% \text { from year } 11 \text { to year } 15\end{array}$ & climateIndicator & $\begin{array}{l}\text { this variable remains } 1 \text { when it is in a baseline scenario, } \\
\text { when it is in a price shock scenario, it becomes } 0.1 \text { and } \\
\text { changes the crop price. Crop price is updated every year by } \\
\text { reading an input file } \\
\text { this variable remains } 1 \text { when it is in a baseline scenario, } \\
\text { when it is in a climate shock scenario, it becomes } 0.1 \text { and } \\
\text { changes the crop yield }\end{array}$ \\
\hline $\begin{array}{l}\text { Development } \\
\text { resilience }\end{array}$ & $\begin{array}{l}\text { Households that can survive } \\
\text { different kinds of shocks by } \\
\text { accumulating capitals and } \\
\text { assets over time }\end{array}$ & $\begin{array}{l}\text { Different states of households' } \\
\text { livelihoods: } \\
\text { nonpoor zone (NP-2) } \\
\text { chronic poor zone (CP-1) } \\
\text { extremely poor zone (EP-0) }\end{array}$ & $\begin{array}{l}\text { trajectory of } \\
\text { perCapitaIncome }\end{array}$ & $\begin{array}{l}\text { calculated as total capital divided by total number of } \\
\text { family members every year in the simulation }\end{array}$ \\
\hline
\end{tabular}


decisions about crops and other production activities based on family age and gender structure (National Research Council 2005, VanWey et al. 2007), or farmers tend to take risk averse decisions (Ellis 1994), or farm households diversify their sources of income (Ellis 1998, Ellis and Allison 2004, Brown et al. 2013). Integration into the market economy is a trend observed in small farm households all over the world, thus many households switch from traditional self-sufficiency to a more market-focused strategy (Vongvisouk et al. 2014). However, studies also suggest that subsistence farming will not be completely eliminated (Tittonell 2014, Malek et al. 2019). In our case, even though manioc is more labor intensive and less profitable than açaí, we noted that there are still households who prefer growing manioc domestically to fulfill their subsistence needs without purchasing from the market (Brondízio et al. 2002, Vogt et al. 2016). In the model, this was implemented as households always grow some açaí and manioc simultaneously for domestic consumption, regardless of the market price of the two items.

\section{MODEL SIMULATION AND RESILIENCE ASSESSMENT}

\section{Model setup: initialization}

The raster landscape represents the forested land of the region, including both tidal floodplain forest (várzea) and upland areas that are not subject to regular flooding. The human submodule initializes household agents across the landscape. Each agent takes possession of $0.5-10$ ha of land surrounding the initial placement as their land property. The demographic and capital resources of household agents coincide with the empirical distribution we found in a household survey that was carried out in 2012 across 600 households (see Dou et al. 2017). At the beginning of each simulation, the distribution of each factor is initialized using the Monte Carlo method, to match the distribution from the survey. In other words, a uniform randomnumber generator is implemented to assign numbers in the range of every characteristic's value based on the questionnaire results. Each simulation runs for a period of 30 years, which begins at tick 1 and ends at tick 30 and each tick represents one year.

\section{Simulation rounds: baseline and shock scenarios}

We simulated three types of hypothetical, yet likely, disturbances to the Caboclos livelihood system: (1) a drop in the price of açaí, (2) an environmental hazard that reduces açaí yield, and (3) a national economic recession that reduces the availability of offfarm jobs, to model household dynamics to these disturbances (Table 1). In the baseline scenario, the value of these variables remained stable over the simulation. In shock scenarios, the value of the corresponding variable was reduced by $90 \%$ from year 11 to year 15 during the 30 -year simulation.

The baseline and shock scenarios were run with all three decision strategy ensembles: within every scenario, all households utilized one livelihood strategy, and every scenario was simulated for all three livelihood strategies, respectively. Every scenario was initialized and run for 30 simulations to lower the randomness, considering the time constraints, the stability of the output (Lee et al. 2015), and other ABM applications (Bousquet et al. 2005, Brown and Robinson 2006, Chen et al. 2014).

\section{Output measurement: define livelihood states}

In each year, we calculated per capita household wealth (accumulated income over time divided by the number of family members) as an indicator for different livelihood states. The three states are those suggested by Barrett and Constas (2014) in development resilience, i.e., humanitarian emergency zone, chronic poverty zone, and nonpoor zone. Here, these three states were renamed for simplicity and quantified as (1) extremely poor (EP-0): per capita wealth is below zero indicating that households need immediate humanitarian assistance; (2) chronic poor (CP-1): per capita wealth is below 6000 monetary units $(\mathrm{R} \$)$ in the model; and (3) nonpoor (NP-2): household per capita wealth is above the poverty threshold 6000 thus nonpoor. We used the average value of the third quartile of per capita wealth at simulation year 10 over all simulations as the threshold (i.e., the poverty line threshold 6000) to divide the chronic poverty and nonpoor zones because such division is consistent with other field research (Carter et al. 2007, Babulo et al. 2008). The same threshold was used across all simulations and scenarios.

Output analysis: probe system interactions

To identify pathways out of poverty, a livelihood tracking system was developed that provides an overall picture of the household's livelihood dynamics. The livelihood state of households was sampled at three crucial points (Carter et al. 2007) during the simulation: before the shock (year 10), immediately after the shock (year 16), and at the end of the simulation (year 30). Each household was assigned a three-digit code in the form $\mathrm{X}-\mathrm{Y}-\mathrm{Z}$ where $\mathrm{X}$ is the state before the shock, $\mathrm{Y}$ is the state after the shock, and $\mathrm{Z}$ is the state at the end of the simulation (Fig. 2). Even though no shock was applied to the baseline scenario, we used the same sampling approach to stay consistent over all scenarios and analyses. At each time point, households can be in one of the three livelihood states mentioned earlier (EP-0, CP-1, and NP-2). For example, a code of 112 means that this household belongs to the chronic poor (CP-1) before and after the shock, and it becomes the nonpoor (NP-2) at the end of the simulation. The code of 100 indicates that a household was chronically poor (CP-1) before the shock but went to extreme-poor (EP-0) and remained there for the rest of the simulation. This method allows a household's trajectory to be tracked at three critical time slots. By looking at the three digits code, it is relatively easy to know the position and dynamics of a household in terms of livelihood outcomes and poverty states. We also used the Sankey diagram, a flow diagram in which the width of arrows is proportional to the quantity of each flow, to visualize the proportion of different livelihood trajectories (visualization was done in $\mathrm{R}$ package networkD3).

To assess the impacts of shocks on smallholders' livelihood trajectories, analysis of variance (ANOVA) was used to check if shock scenarios affected certain livelihood trajectories by comparing the percentage of households in one observed trajectory between the baseline scenario and the shock scenarios. For instance, $5 \%$ of households were found to have followed the 110 trajectory (chronically poor before and after the shock, ended up in extreme poverty) under the baseline scenario, but that number increased to $10 \%$ of households under an açaí shock scenario. This suggests that with the introduction of açaí shock, $5 \%$ more households ended up in poverty compared to the baseline. 
Fig. 2. Examples of household development trajectory. Three panels are from three individual simulation scenarios. The $\mathrm{x}-$ axis represents the simulation year and $y$ is the per capita household wealth. Every black dot is one specific household's per capita wealth $\mathrm{Y}$ at year $\mathrm{X}$, and the line shows one single household wealth trajectory over one year. The three rectangles with red dashed lines indicate the time point that we record household's state, which are Year 10 (before shock), 16 (after shock), and 30 (at the end of simulation). The two green lines indicate the two thresholds that distinguish the three livelihood states. The gray panel is when a shock is applied to the simulation during year 11 and 15 .

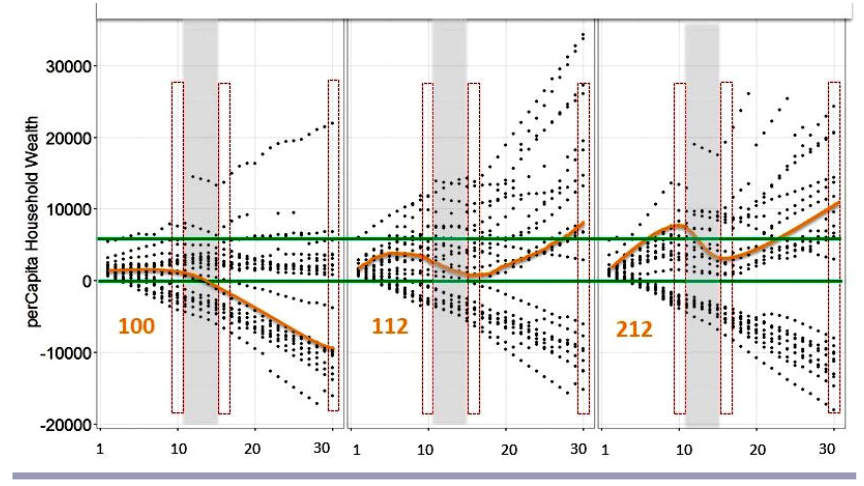

\section{Exploring sources of resilience}

To disclose the sources of resilience in the livelihood systems and critical turning points, we used statistical analyses (e.g., anova and t-test) that measure the contribution of different factors to resilience, thereby identifying possible leverage points. We explored two key pathways: (1) what kinds of households stayed in the nonpoor zone, i.e., households were nonpoor (NP-2) at the beginning of the simulation and stayed that way; (2) what kinds of households were lifted out of poverty over time, i.e., households were formerly poor but ended up in the nonpoor zone (NP-2). We suggest that the household characteristics identified as statistically significant in these analyses are the key factors and might represent leverage points in the smallholder livelihood system for poverty alleviation.

Livelihoods are influenced by a variety of factors, including assets and capabilities, as well as the strategies that households employ. The factors that were examined included (also indicated in Table 1): (1) households' initial wealth, i.e., household total wealth, per capita wealth; (2) labor capacity and subsistence requirement; (3) human capital, i.e., husband education and average school year of female members; (4) land type (floodplain and upland) and the size of their land; and (5) decision strategy (Max Profit, Just Enough, and Subsistence First). Both (4) land type and (5) decision strategies are categorical data. Other factors were removed from analyses because of the high correlation (e.g., dependence ratio, household size).

To answer the first question, we used a t-test to compare the initial characteristics (e.g., the characteristics at year 1, the beginning of the simulation) of households that started in different livelihood states before the shock. We did not specify a baseline or shock scenario because the first stage had not been affected by shocks. The results can reveal what types of households are in the nonpoor zone (NP-2) to begin with, which are not at risk regardless of the shock.

The second question was answered by two subsequent analyses, focusing on households that are in the chronic poor (CP-1) group before shocks: first, we compared the characteristics of households in different livelihood trajectories (1XX) between baseline and shock scenarios; second, we compared households from different livelihood trajectories within the shock scenarios. We looked for factors that are statistically significant (and those that are insignificant) among households that end up in nonpoor states between baseline and shocks, which reveals the important characteristics to keep households out of poverty when a shock attacks the system. If a variable is insignificant between different livelihood trajectories within shock scenarios, it may not be an important source of resilience for households to stay out of poverty under shocks and vice versa. For categorical variables, such as land types and livelihood strategies, we used a chi-square test to compare the proportion of each category in different groups. For numeric variables, we used a t-test to compare the group mean.

\section{RESULTS}

\section{Livelihood trajectories}

\section{Observed livelihood trajectories}

Three-digit codes provide a snapshot of a household's livelihood dynamics at three points in time (Fig. 2). Although some details may be missed, collectively the codes give an indication of a household's trajectory over time. Theoretically, a household can be in any livelihood state (EP-0, CP-1, and NP-2) at each of the times when that state is recorded, before a shock (year 10), after a shock (year 16), and at the end of the simulation (year 30). Because there are 3 possible livelihood states at each of the 3 sample points, there are 27 possible types of trajectories $\left(3^{3}\right)$. However, only 14 of these trajectories were ever observed, with only 8 of these trajectories occurring in a proportion larger than $1 \%$ in any simulation (as indicated with $\dagger$ and $\$$ in Table 2 ). These eight observed codes reveal the range of possible livelihood trajectories for these households over time.

Table 2. Potential and observed livelihood trajectories.

\begin{tabular}{llllllllll}
\hline \hline $0-X X$ & 000 & $001^{\dagger}$ & $002^{\dagger}$ & $010^{\dagger}$ & $011^{\dagger}$ & $012^{\dagger}$ & $020^{\dagger}$ & $021^{\dagger}$ & $022^{\dagger}$ \\
$1-X X$ & 100 & $101^{\dagger}$ & $102^{\dagger}$ & 110 & $111^{\dagger}$ & 112 & $120^{\dagger}$ & $121^{\dagger}$ & 122 \\
$2-X X$ & $200^{\dagger}$ & $201^{\dagger}$ & $202^{\dagger}$ & $210^{\dagger}$ & $211^{\dagger}$ & 212 & $220^{\dagger}$ & $221^{\dagger}$ & 222 \\
\hline
\end{tabular}

${ }^{\dagger}$ Household trajectory not observed in these simulations.

${ }^{\dagger}$ Household trajectory observed with a frequency below $1 \%$.

Households that started from the extremely poor state (EP-0) remained there over the next two stages (coded as 000; Fig. 3, the pink flow at the bottom). Besides 000 , no other trajectories were observed with first digit EP-0 (e.g., 010 or 021). This indicates that if a household began from an extremely poor state, it cannot escape poverty. On the contrary, if the first observed state was the nonpoor state (NP-2), the last observed state was always NP-2 as well. Only trajectories 212 and 222 were found in our simulations 
with a frequency greater than $1 \%$. Very few households that started with NP-2 stayed in other trajectories (e.g., no trajectory 201 or trajectory 221 was observed). This indicates that once a household reached this nonpoor zone, they were able to remain there or return there following a shock. These households fit the description of development resilience as those who settle in the high well-being zone.

Fig. 3. Households' livelihood state at the sampled time slots (baseline). The bottom is the extremely poor (EP-0) state, the middle panel is the chronic poor (CP-1), and the top section is the nonpoor (NP-2). The left panel is the before shock time slot, middle panel is the after shock point, and the right panel is the end of simulation slot. All households from EP-0 before shock stayed as EP-0 over the simulation and ended up at EP-0 at the end of simulation. All households from NP-2 before shock stayed as NP-2 over simulation. Some CP-1 households before shock joined the NP-2 at the end, and there was a small group of $\mathrm{CP}-1$ before shock that ended up at the EP-0 at the end of simulation.

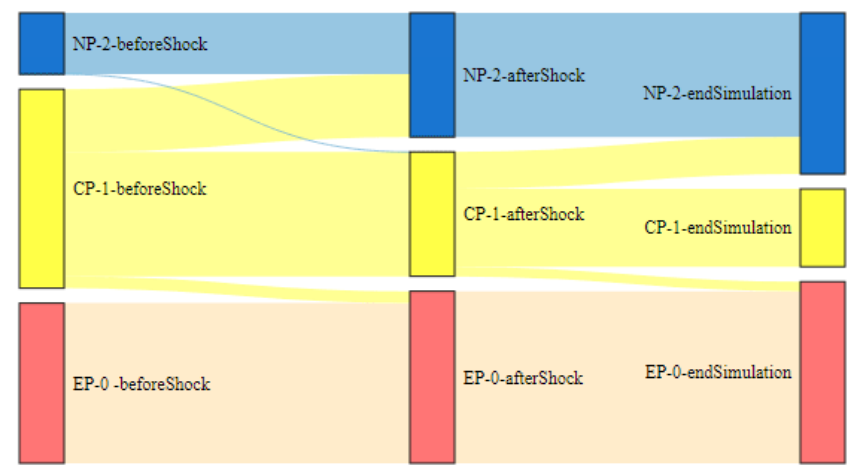

Households that began the simulation in the chronic poor (CP-1) state were observed to finish the simulation period in any of the three livelihood states. For instance, households that began in the CP-1 state followed 100 and 110 trajectories, indicating that they moved to the extremely poor state by the end of the 30-year simulation. Some households followed the 111 trajectory, indicating that they stayed in the chronic poor zone throughout the simulated period. However, some households reached the nonpoor state by the end of the simulation. Additionally, it is worth noting that no 101 or 102 trajectories were observed. This pattern, aligned with the above-mentioned observation that if a household began as an extremely poor always ended up in the EP-0 state, indicates the existence of a poverty trap in the simulation. In addition, no trajectories of 120 or 121 were observed, suggesting that once a household reached a nonpoor zone, it was less likely to drop out of this well-off position.

\section{Impacts of shocks on household livelihood trajectories}

There was no significant difference between the number of households that followed the 000 trajectory in the baseline scenario and shock scenarios (Table 3). These persistently extremely poor households were present in all situations. The shock scenarios had only a minor impact on households that started in the nonpoor zone. Under shocks, about $1.9 \%$ of households dropped temporarily out of the nonpoor zone to the chronic poor zone. However, these households returned to the nonpoor state by the end of the simulation.

Table 3. Percentage change of households in every livelihood trajectory

\begin{tabular}{lcccc}
\hline \hline Trajectory & Baseline $(\%)$ & Shock Scenarios $(\%)$ & Change & T-test \\
\hline 000 & 37.9 & 37.7 & & NS \\
100 & 2.8 & 8.7 & 5.88 & $*$ \\
110 & 2.3 & 3.5 & 1.25 & $*$ \\
111 & 18.4 & 16.0 & & NS \\
112 & 8.7 & 15.6 & 6.85 & $*$ \\
122 & 14.9 & 4.9 & -10.02 & $*$ \\
212 & 0.0 & 1.9 & 1.85 & $*$ \\
222 & 14.5 & 11.3 & -3.21 & $*$ \\
\hline
\end{tabular}

$* \mathrm{P}<0.05$.

NS: not significant.

Between the two states of the extremely poor (EP-0) and the nonpoor (NP-2), households starting in the chronic poor zone (i.e., the trajectory group $1-\mathrm{XX}$ ) were the ones most likely influenced by events. Shocks significantly increased the number of households that ended the simulation within the extremely poor state (e.g., 5.88\% more of the trajectory 100 and $1.25 \%$ more with trajectory 110 ). An additional $3.17 \%$ of households failed to reach the nonpoor zone under shock scenarios compared to those in the baseline scenario (i.e., as the difference between the sum of the 112 and 122 in the baseline scenario, which are 8.7 and 14.9, and the shock scenarios, which are 15.6 and 4.9).

Fig. 4. Households' livelihood state at the sampled time slots (shock scenarios). The bottom is the extremely poor (EP-0) state, the middle panel is the chronic poor (CP-1), and the top section is the nonpoor (NP-2). Description is the same as Figure 3, however, the proportion of flows is different from Figure 3.

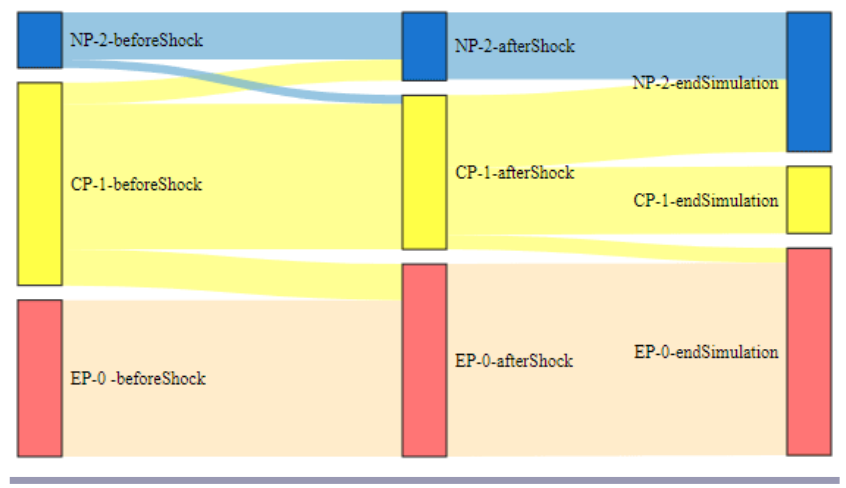

\section{Characteristics of households in different trajectories}

Initial household characteristics

In Table 4, we present the average value of initial household characteristics summarized from three livelihood states pinpointed before the shock (year 10). Results show that households that began in the extremely poor state (EP-0) were 
Table 4. Initial household characteristics among households that end up in different livelihood states. Note: EP= extreme poverty, CP $=$ chronic poverty, and $\mathrm{NP}=$ nonpoor.

\begin{tabular}{|c|c|c|c|c|c|c|c|c|c|c|}
\hline & \multicolumn{2}{|c|}{ Labor } & \multicolumn{2}{|c|}{$\begin{array}{l}\text { Subsistence } \\
\text { requirement }\end{array}$} & \multicolumn{2}{|c|}{ Initial capital } & \multicolumn{2}{|c|}{ Initial per capita wealth } & \multicolumn{2}{|c|}{ Land size } \\
\hline & mean & sd & mean & $\mathrm{sd}$ & mean & sd & mean & $\mathrm{sd}$ & mean & sd \\
\hline EP-0 & 1 & 0.327 & 2809 & 789.8 & 5830 & 1807 & 1081 & 468 & 660.04 & 367.61 \\
\hline $\mathrm{CP}-1$ & 0.81 & 0.376 & 2581 & 831.5 & 8430 & 2405 & 1630 & 671 & 695.07 & 314.57 \\
\hline NP-2 & 0.95 & 0.214 & 2062 & 758.3 & 9101 & 2117 & 2117 & 693 & 683.05 & 317.35 \\
\hline \multirow[t]{3}{*}{ ANOVA } & \multicolumn{2}{|c|}{ * } & \multicolumn{2}{|c|}{ * } & \multicolumn{2}{|c|}{$*$} & \multicolumn{2}{|l|}{ * } & \multicolumn{2}{|c|}{ * } \\
\hline & \multicolumn{2}{|c|}{ Husband Education } & \multicolumn{2}{|c|}{$\begin{array}{l}\text { Average female } \\
\text { education }\end{array}$} & $\begin{array}{c}\text { Just } \\
\text { Enough }\end{array}$ & $\begin{array}{l}\text { Max } \\
\text { Profit }\end{array}$ & Subsistence First & Upland & \multirow[t]{2}{*}{ Várzea } & \\
\hline & mean & sd & mean & sd & & & & & & \\
\hline EP-0 & 3.37 & 2.3 & 2.31 & 2.63 & $11 \%$ & $12 \%$ & $15 \%$ & $37 \%$ & $1 \%$ & \\
\hline CP-1 & 3.68 & 2.35 & 2.34 & 2.69 & $22 \%$ & $15 \%$ & $12 \%$ & $14 \%$ & $35 \%$ & \\
\hline NP-2 & 3.68 & 2.53 & 2.86 & 2.68 & $0 \%$ & $7 \%$ & $7 \%$ & $0 \%$ & $13 \%$ & \\
\hline ANOVA & \multicolumn{2}{|c|}{$*$} & \multicolumn{2}{|c|}{ * } & & & & & & \\
\hline
\end{tabular}

$* \mathrm{P}<0.05$

Labor is a measure of family members who can perform heavy labor, which counts adult male as one and female as 0.5 , teenagers and elders are calculated as a proportion. Subsistence requirement, initial capital, and initial per capita capital were all in the monetary unit R\$. Dependent ratio, total labor, and number of household numbers were removed from the analysis because of high correlation with labor and subsistence requirement. Várzea and upland were presented as percentage in total number of households, so were the three livelihood strategies. Decision strategies and land types are both significant in end states according to chi-square test, $\mathrm{p}<0.05$.

different from the other two livelihood states in almost all aspects initially, including labor, capital, education, land, and livelihood strategies. These families had the highest labor capacity, which can contribute to intensive labor activities, and they also had lower capital endowment (e.g., initial capital and per capita wealth), education (e.g., average female education), and land size, compared to households in NP-2 and CP-1. For example, the average subsistence requirement for EP-0 was R $\$ 2809$ whereas this value was only 2581 and 2062 for the CP-1 and NP-2, respectively. Households in the group EP-0 also had the lowest initial capital and per capita wealth, which were only $64 \%$ and $51 \%$ of the average value for the group NP-2. In addition, land was another distinguishable character. Almost all households in the EP-0 were on upland with a small plot. There was no dominant livelihood strategy among households in the EP-0.

Households in NP-2 were better off among the three groups in many aspects except land size. They had the highest per capita capital (i.e., R \$2117 compared to R \$1630 in CP-1 and R \$1081 in EP-0) and total capital (i.e., R \$9101 compared to R \$8430 in CP-1 and R\$5830 in EP-0). They had the lowest subsistence requirement among the three and their labor ranked second. These households also had the highest average female education value and husband education among the three groups. The land size, however, was not the largest among the three. The most distinguished characteristics were the land type and the livelihood strategy. All households in NP-2 were in várzea and none of them utilized the Just Enough livelihood strategy.

Characteristics of households in the chronic poor zone

In Table 5, we present the initial characteristics of households in different livelihood trajectories that all began in the chronic poor zone (1-XX). The initial characteristics of households show nonlinearity. There was no simple increasing or decreasing trend in any of these characteristics from the poorer trajectories (e.g., 100 and 110) to the well-off trajectories (e.g., 112 and 122).

Demography was a key factor for households that ended up in extreme poverty under both shock and baseline scenarios.
Households with larger families and higher subsistence requirements were more likely to drop to poverty in the shock scenarios compared to the baseline (Table 5). For instance, the subsistence requirements for households in the trajectory 100 and 110 in the baseline started with $\mathrm{R} \$ 2218$ and $\mathrm{R} \$ 2236$, respectively. However, for households in these two trajectories in the shock scenarios, the average subsistence requirement increased to $\mathrm{R} \$ 2610$ and $\mathrm{R} \$ 2561$. This is due to more large families that ended up in poverty in the shock scenario than in the baseline scenario, causing a higher average subsistence requirement. Households that were able to maintain an upward trend and reach a prosperous state at the end (e.g., 112 and 122) had higher initial capital in the shock scenarios compared to the baseline. It is more complicated with the education factor because the husband education level of trajectory 122 was higher in the shock scenario compared to the baseline, although the average female education level showed no significant difference.

The percentage of land type between baseline and shock scenarios was significantly different in most livelihood trajectories including 100, 110, and 112. In the baseline scenario, the dominant land type in 100 and 110 was upland, but about $8 \%$ more households in the várzea floodplain also dropped to the extreme poor state in the shock scenarios. However, for households that were able to reach the nonpoor zone (NP-2) at the end (112), more had várzea floodplain in the shock scenario compared to the baseline scenario, which may have been in the trajectory of 122 in the baseline scenario. On the contrary, no significant difference was identified in land size among all livelihood trajectories between scenarios.

Furthermore, livelihood strategies showed noticeable differences between baseline and shock scenarios. There were more households in less favorable trajectories in the shock scenarios compared to the baseline, regardless of the strategy used based on the chi-square test. However, more Just Enough and Max Profit households ended up in these trajectories $(8 \%$ and $5 \%$, respectively) in shock scenarios, compared to the change of ratio 
Table 5. Initial household characteristics among different trajectories of chronic poor households.

\begin{tabular}{|c|c|c|c|c|c|c|c|c|c|}
\hline & \multicolumn{3}{|c|}{ Labor } & \multicolumn{3}{|c|}{ Subsistence requirement } & \multicolumn{3}{|c|}{ Initial capital } \\
\hline & baseline & shock & & baseline & shock & & baseline & shock & \\
\hline 100 & 0.59 & 0.8 & $*$ & 2218 & 2610 & * & 7883 & 7469 & NS \\
\hline 110 & 0.52 & 0.71 & $*$ & 2236 & 2561 & * & 9334 & 8929 & NS \\
\hline 111 & 0.83 & 0.8 & NS & 2799 & 2662 & * & 8634 & 8730 & NS \\
\hline 112 & 0.75 & 0.84 & $*$ & 2262 & 2506 & * & 7945 & 8293 & * \\
\hline \multirow[t]{3}{*}{122} & 0.91 & 0.86 & $*$ & 2624 & 2547 & NS & 8543 & 9011 & * \\
\hline & \multicolumn{3}{|c|}{ Initial per capita wealth } & \multicolumn{3}{|c|}{ Husband education } & \multicolumn{3}{|c|}{ Average female education } \\
\hline & baseline & shock & & baseline & shock & & baseline & shock & \\
\hline 100 & 1613 & 1479 & $*$ & 3.58 & 3.41 & NS & 3.34 & 2.42 & * \\
\hline 110 & 1969 & 1757 & NS & 4.84 & 4.33 & NS & 2.16 & 1.96 & NS \\
\hline 111 & 1647 & 1732 & $*$ & 3.73 & 3.78 & NS & 2.23 & 2.40 & NS \\
\hline 112 & 1779 & 1558 & $*$ & 4.02 & 3.60 & $*$ & 2.71 & 2.35 & NS \\
\hline \multirow[t]{3}{*}{122} & 1512 & 1639 & $*$ & 3.26 & 3.58 & * & 2.14 & 2.35 & NS \\
\hline & \multicolumn{2}{|c|}{ Just Enough } & & \multicolumn{2}{|c|}{ Max Profit } & \multicolumn{4}{|c|}{ Subsistence First } \\
\hline & baseline & shock & * & baseline & shock & * & baseline & shock & * \\
\hline 100 & $2 \%$ & $9 \%$ & & $2 \%$ & $6 \%$ & & $2 \%$ & $3 \%$ & \\
\hline 110 & $3 \%$ & $4 \%$ & & $1 \%$ & $2 \%$ & & $1 \%$ & $2 \%$ & \\
\hline 111 & $33 \%$ & $27 \%$ & & $4 \%$ & $4 \%$ & & $2 \%$ & $3 \%$ & \\
\hline 112 & $7 \%$ & $6 \%$ & & $6 \%$ & $14 \%$ & & $5 \%$ & $13 \%$ & \\
\hline \multirow[t]{3}{*}{122} & $2 \%$ & $0 \%$ & & $16 \%$ & $5 \%$ & & $14 \%$ & $4 \%$ & \\
\hline & \multicolumn{3}{|c|}{ Land size } & \multicolumn{2}{|c|}{ Upland } & & \multicolumn{2}{|c|}{ Várzea } & \\
\hline & baseline & shock & & baseline & shock & * & baseline & shock & * \\
\hline 100 & 729.9 & 710.3 & NS & $5 \%$ & $12 \%$ & & $1 \%$ & $6 \%$ & \\
\hline 110 & 640.4 & 705.0 & NS & $5 \%$ & $5 \%$ & & $0 \%$ & $3 \%$ & \\
\hline 111 & 698.1 & 698.6 & NS & $12 \%$ & $9 \%$ & & $27 \%$ & $24 \%$ & \\
\hline 112 & 669.7 & 684.9 & NS & $6 \%$ & $3 \%$ & & $13 \%$ & $29 \%$ & \\
\hline 122 & 679.6 & 693.6 & NS & $1 \%$ & $1 \%$ & & $30 \%$ & $9 \%$ & \\
\hline
\end{tabular}

* indicates T-test and chi-square test result (a p-value < 0.05$)$ between baseline and shock scenario; NS stands for not statistically significant.

among Subsistence First households (2\%). A similar number of households that used Max Profit and Subsistence First followed a favorable trajectory (e.g., 112 and 122) in baseline and shock scenarios. For example, $19 \%$ of households that adopted Subsistence First reached the nonpoor zone in the baseline and $17 \%$ in the shock scenarios. The dominant livelihood strategy among households that ended up in the chronic poor zone (111) was Just Enough, in both baseline (33\%) and shock scenarios $(27 \%)$ whereas only $2 \%$ of households used Subsistence First in the baseline in comparison.

Characteristics among chronic poor households that ended up in different states in the shock scenarios

The results of the comparison across households that all set off from CP-1 but ended up in different livelihood states reveal which characteristics are important when dealing with a shock (Table 6). Labor and subsistence requirements were significantly different between households that stayed in CP-1 and those that reached NP-2. Households that ended up in NP-2 had higher available labor but less subsistence requirement. Surprisingly, these households that ended up in NP-2 had lower husband education levels, lower initial capital, and per capita wealth compared to the CP-1. The average female education level and land size were not significant among households that reached NP-2 and those that stayed in CP-1. It is noteworthy that the dominant land type in both $\mathrm{CP}-1$ and NP-2 was várzea, and upland among households in the EP-0 according to the chi-square test. The dominant livelihood strategies in each end-stage state were different based on the chi-square test. In the EP-0, half of the households followed the Just Enough strategy, whereas among those that reached the nonpoor zone, only $14 \%$ followed Just
Enough. Around $44.7 \%$ of the households that reached the nonpoor zone used Max Profit and 41.0\% were Subsistence First adopters.

\section{DISCUSSION}

\section{Alternative states of livelihood systems}

This study illustrates the livelihood trajectories of smallholders in the Brazilian Amazon estuary region using the concept of development resilience and an agent-based modeling approach. The simulation results demonstrate possible ranges of pathways that are consistent with observations from resilience theories and alternative states of the system (Walker et al. 2004). The three states based on development resilience theory, extreme poor (EP-0), chronic poor (CP-1), and nonpoor (NP-2), represent three alternative states that smallholder households can reside in. Households that started off or entered the extremely poor zone were likely to remain in that state. Households that started from or entered into the nonpoor zone generally had the resources to remain there, even when suffering from temporary shocks. Hence, it is clear that the nonpoor state is favorable for poverty reduction, whereas the opposite holds true for the extreme poor as the nondesirable state for the outcome of the livelihood system. Often, households in the nonpoor state were small and wealthier households that favored Max Profit or Subsistence First strategies. On the other hand, extremely poor households, which often adopted the Just Enough strategy on the upland, seemed to require abundant resources to come out of poverty.

Chronic poor households that fall in the middle and between the extremely poor and nonpoor are of particular interest because of their potential for upward mobility. From the perspective of 
Table 6. Comparing characteristics of chronic poor households in three livelihood states within shock scenarios. Note: EP = extreme poverty, $\mathrm{CP}=$ chronic poverty, and $\mathrm{NP}=$ nonpoor.

\begin{tabular}{|c|c|c|c|c|c|c|}
\hline End state & Labor & Subsistence requirement & Husband education & Average female education & Initial capital & Initial per capita wealth \\
\hline EP-0 & 0.78 & 2595.26 & 3.67 & 2.29 & 7891.94 & 1559.68 \\
\hline $\mathrm{CP}-1$ & 0.79 & 2654.01 & 3.80 & 2.39 & 8765.59 & 1742.29 \\
\hline NP-2 & 0.85 & 2515.70 & 3.59 & 2.35 & 8463.87 & 1577.00 \\
\hline 0 and 1 & NS & $*$ & NS & NS & $*$ & $*$ \\
\hline 1 and 2 & $*$ & $*$ & $*$ & NS & $*$ & $*$ \\
\hline End state & Land size & Várzea & Upland & Just Enough & Max Profit & Subsistence First \\
\hline EP-0 & 708.81 & $34.83 \%$ & $65.17 \%$ & $50.0 \%$ & $30.0 \%$ & $20.0 \%$ \\
\hline $\mathrm{CP}-1$ & 698.77 & $73.85 \%$ & $26.15 \%$ & $80.2 \%$ & $11.8 \%$ & $8.0 \%$ \\
\hline NP-2 & 686.97 & $91.15 \%$ & $8.85 \%$ & $14.3 \%$ & $44.7 \%$ & $41.0 \%$ \\
\hline 0 and 1 & NS & * & & $*$ & & \\
\hline 1 and 2 & NS & $*$ & & $*$ & & \\
\hline
\end{tabular}

enhancing development resilience, these households require special attention to prevent them from dropping into extreme poverty and to be pushed to the nonpoor zone. However, the results show the complexity of smallholder livelihood systems because there is no monotonic increasing or decreasing trend across factors. For instance, chronic poor households that reached the nonpoor zone at the end of the simulation were not well-off in their initial capital endowment. In addition, they were relatively large families with a high subsistence requirement. This shows an opposite trend compared to the households that started from the nonpoor zone, which highlights the need for tailored interventions. This is particularly true for education and land size. Surprisingly, both education and land size are not statistically significant in trajectories between baseline and shock scenarios. Livelihood strategies and land types, on the other hand, were more consistent across scenarios and trajectories. Households on várzea could produce abundant cash crops and were more likely to reach prosperity, so were households that followed Max Profit and Subsistence First strategies. This suggests that along with the conventional approach focusing on improving the capitals and assets of households, changing households' strategies is another, perhaps more effective, way to increase development resilience. Incentives and approaches to stimulate households to adopt suitable strategies will be analyzed and tested in our future work.

\section{Narratives of fieldwork observations to elaborate livelihood strategies and outcomes}

Our results coincide with fieldwork observations. Several families are investing in at least one member seeking education and offfarm employment to diversify the household livelihood portfolio. The employed family member may at times move to an urban center but the household members continue to share income and subsistence products with each other, an arrangement called multisited households (Padoch et al. 2008). These households with diversified livelihoods focus on commercial production and maintain floodplain land use and agro-biodiversity so they can rapidly return and intensify a broader subsistence portfolio, even between single seasons, if income drops unexpectedly (Vogt et al. 2016). In good harvest years, small excess cash and benefits are often invested in extensional education programs that can lead to more employment, in motorboats and nets for more lucrative commercial fishing in the main channel of the delta, or horticulture and small animal husbandry. There is another group that is optimizing commercial activities on-farm and off-farm incomes and sharing incomes among household members across multiple sites.

The Just Enough families seem to have emerged from a combination of two factors: the açaí boom, which provided just adequate food and income to purchase other food items, and the government benefits for poor families. These families are satisfied with their livelihood and do not invest in education, off-farm employment, or commercial factors. Some young families with limited labor to contribute to household income or livelihoods are very vulnerable to açaí burning (as a type of climatic shock). In shock years, even working hard, they produce only enough to subsist with reduced quantity and diversity of diets. These households often become more dependent on elder parents or relatives who receive retirement benefits from the government. As indicated in the results, Just Enough households barely reach the nonpoor state and are more likely to end up in extreme poor or chronic poor states.

\section{Policy recommendations}

Three general options for improving development resilience were recommended by Barrett and Constas (2014): (1) shift people's current state by increasing households' capacity and resource base; (2) reduce risk exposure by introducing new technologies; (3) change system structures by changing people's behaviors. Our analyses from the simulation output provide evidence for the first and third approaches but for different types of households. For example, smaller and wealthier households on the floodplains are more likely to remain in the nonpoor state, which suggests that increasing households' capacity, particularly as it relates to demography and land resource for cash crops, could possibly elevate households into the nonpoor zone to prevent any dropout. This is particularly useful when households are extremely poor because our results indicate no dominant livelihood strategies among households in the extremely poor states; changing their behavior may not be enough when there is a need to improve their assets first. 
Conventional poverty reduction approaches in Brazil, such as Bolsa familia or pension cash transfer programs that are provided by the Brazilian government for children and elders (Dou et al. 2017), are designed to directly improve households' assets on capital, education, and land areas. These programs have been found to be effective in poverty reduction (Barrientos and NiñoZarazùa 2011). However, they often have enormous costs (about $0.5 \%$ of the Brazilian gross domestic production) and may not be sustainable in the long run especially under the country's increasing political and economic instability. As indicated by the results in shock circumstances, households starting in the chronic poor state may not need the highest capital to reach the nonpoor state. This suggests that increasing capital may not be the most effective way to help chronic poor households.

The consistency of people's behaviors contributing to different livelihood states and trajectories from our simulations matches the target of the third approach, which is to change the system structure and people's behaviors. In the results, Just Enough households rarely reached the nonpoor zone and they were more likely to end up in the extremely poor state. On the contrary, Max Profit and Subsistence First strategies were more likely to lift people into out of poverty. However, Subsistence First households performed more resiliently under shocks than Max Profit households. Changing people's behavior is the centerpiece of the livelihood systems perspective, which emphasizes empowering people to pursue resilient livelihoods (Krantz 2001, Coppock 2011). Results indicate that the choice of different livelihood strategies is more likely to be one of the most important contributors to livelihood outcomes and trajectories. This broadens the traditional perspectives when designing policies for resilience from capacity building to empowering people with alternative livelihood strategies.

\section{Limitations of the current study and outlooks}

In our analysis, we used a simple three-digit tracking system on per capita capital as the trajectory indicator. Using one sole indicator may overlook some underlying changes within a household livelihood system, including their changed capacity, e.g., land expansion and increased experience as mentioned in Barrett and Constas (2014). Considering that the trade-off of having an elaborated set of indicators is to increase the complexity of the model and the analyses, we think the choice of capital as an indicator can provide a sufficient picture of the dynamics as a first step; the accumulated wealth is generated by different livelihood activities over time and affected by all household characteristics.

In our simulation, all agents only use one livelihood strategy within each simulation. This may not always be the case in the real world. Households from the same community would very likely choose different strategies, and households can use transformative adaptation strategies when facing shocks. In this simulation, we wanted to present ranges and potentials of different outcomes by using alternative decision-making strategies, rather than empirically calibrating the adoption of each strategy in the population. This particular research interest will be explored in the future.

\section{CONCLUSION}

We explored how smallholder livelihoods can be simulated by an agent-based model within the development resilience framework. A tracking method was used to show the trajectory of livelihood dynamics, which identified vulnerable households and households that can be lifted upward. These results support the three livelihood states in development resilience, including one favorable state, the nonpoor zone in which households are resilient enough to survive shocks, and one less-desirable state, the poverty trap in which households are less likely to escape.

The simulation results and analyses also revealed the possible pathways by which currently poor households can escape and reach a prosperous state. Based on the findings, we recommended policy directions that increase household resources (e.g., land types) and empower people to adopt alternative livelihood strategies. We hope this application of agent-based modeling in smallholder livelihoods and its simulation of development resilience will contribute to a collective base of evidence about the pathways underlying livelihoods, poverty, and resilience. Armed with these theories and knowledge, researchers and policymakers can better understand and support smallholders so that they can achieve prosperity.

Responses to this article can be read online at: http://www.ecologyandsociety.org/issues/responses. php/11842

\section{Acknowledgments:}

This research was supported by the International Development Research Centre (IDRC) of Canada (project: Socio-Cultural Adaptations of Caboclos in the Amazon Estuary of Brazil to Extreme Tidal Events), CAPES-PROAMAZONIA-3322/2013, CNPQ-455378/2014-2, and FAPESP 2017/10105-5. We are grateful to the reviewers of this paper who provided constructive and thorough feedback that has greatly improved this manuscript. In addition, we thank colleagues who shared insightful discussion and ideas for the manuscript. We also thank a number of institutions and individuals in Brazil who made this work possible, including the Universidade Federal do Para, Josiel Vilhena from Federal Institute of Pará State (IFPA) that participated in the selecting and training of IFPA students for the data collection, as well as Walter Ubal of IDRC for his advice and assistance. A final special thank you to the many families and individuals of the communities of Abaetetuba for their time and patience during the interviews, particularly Dona Gita for accommodation support during the data collection .

\section{Data Availability:}

The ODD description of our model and the code are available at CoMSES/OpenABM website: https://www.comses.net/codebases/8aa00021e4d3-4468-aa6d-f6c474e459e0/releases/1.0.0/

\section{LITERATURE CITED}

An, L. 2012. Modeling human decisions in coupled human and natural systems: review of agent-based models. Ecological Modelling 229:25-36. https://doi.org/10.1016/j.ecolmodel.2011.07.010

Babulo, B., B. Muys, F. Nega, E. Tollens, J. Nyssen, J. Deckers, and E. Mathijs. 2008. Household livelihood strategies and forest dependence in the highlands of Tigray, Northern Ethiopia. 
Agricultural Systems 98(2):147-155. https://doi.org/10.1016/j. agsy.2008.06.001

Barlett, P. F., editor. 1984. Agricultural decision making: anthropological contributions to rural development. Academic Press, Cambridge, Massachusetts, USA.

Barrett, C. B., and M. A. Constas. 2014. Toward a theory of resilience for international development applications. Proceedings of the National Academy of Sciences 111(40):14625-14630. https:// doi.org/10.1073/pnas.1320880111

Barrientos, A., and M. Niño-Zarazùa. 2011. Social transfers and chronic poverty: objectives, design, reach and impact. Chronic Poverty Research Centre, Overseas Development Institute, London, UK. [online] URL: https://mpra.ub.uni-muenchen. de/30465/1/Barrientos and Nino-Zarazua 2011 Social Transfers and Chronic Poverty. Objectives design reach and impact. pdf

Blumenstock, J., G. Cadamuro, and R. On. 2015. Predicting poverty and wealth from mobile phone metadata. Science 350 (6264):1073-1076. https://doi.org/10.1126/science.aac4420

Bousquet, E. F., G. Trébuil, and B. Hardy. 2005. Companion modeling and multi-agent systems for integrated natural resource management in Asia. International Rice Research Institute, Los Baños, Philippines. [online] URL: http://cormas.cirad.fr/pdf/ AsiaBook/all.pdf

Brondízio, E. S. 2004. Agriculture intensification, economic identity, and shared invisibility in Amazonian peasantry: Caboclos and colonists in comparative perspective. Culture and Agriculture 26(1-2):1-24. https://doi.org/10.1525/cag.2004.26.1-2.1

Brondízio, E. S. 2008. The Amazonian Caboclo and the Açai Palm: forest farmers in the global market. First edition. New York Botanical Garden, New York, New York, USA.

Brondízio, E. S., and E. F. Moran. 2008. Human dimensions of climate change: the vulnerability of small farmers in the Amazon. Philosophical Transactions of the Royal Society of London. Series B, Biological Sciences 363(1498):1803-1809. https://doi. org/10.1098/rstb.2007.0025

Brondízio, E. S., A. C. B. de Lima, S. Schramski, and C. Adams. 2016. Social and health dimensions of climate change in the Amazon. Annals of Human Biology 43(4):405-414. https://doi. org/10.1080/03014460.2016.1193222

Brondízio, E. S., C. A. M. Safar, and A. D. Siqueira. 2002. The urban market of Açaí fruit (Euterpe oleracea Mart.) and rural land use change: ethnographic insights into the role of price and land tenure constraining agricultural choices. Urban Ecosystems 6:67-97. https://doi.org/10.1023/A:1025966613562

Brown, D. G., A. Agrawal, D. A. Sass, J. Wang, J. Hua, and Y. Xie. 2013. Responses to climate and economic risks and opportunities across national and ecological boundaries: changing household strategies on the Mongolian plateau. Environmental Research Letters 8(4):045011. https://doi. org/10.1088/1748-9326/8/4/045011

Brown, D. G., and D. T. Robinson. 2006. Effects of heterogeneity in residential preferences on an agent-based model of urban sprawl. Ecology and Society 11(1):46. https://doi.org/10.5751/ ES-01749-110146
Cabrera, A. R., P. Deadman, E. S. Brondizio, and M. PinedoVasquez. 2010. Exploring the choice of decision making method in an agent based model of land use change. In D. A. Swayne, W. Yang, A. A. Voinov, A. Rizzoli, and T. Filatova, editors. 2010 international congress on environmental modelling and software: modelling for environment's sake. International Environmental Modelling and Software Society, Fifth Biennial Meeting, Ottawa, Ontario, Canada. [online] URL: https://scholarsarchive.byu.edu/ cgi $/$ viewcontent .cgi? article $=2418 \&$ context $=$ iemssconference

Carter, M. R., P. D. Little, T. Mogues, and W. Negatu. 2007. Poverty traps and natural disasters in Ethiopia and Honduras. World Development 35(5):835-856. https://doi.org/10.1016/j. worlddev.2006.09.010

Chambers, R., and G. R. Conway. 1991. Sustainable rural livelihoods: practical concepts for the 21 st century. IDS Discussion Paper, 296. Institute of Development Studies, Brighton, UK. [online] URL: https://www.ids.ac.uk/download.php?file=files/ Dp296.pdf

Chayanov, A. V. 1966. The theory of peasant economy. First edition. Richard D Irwin, Homewood, Illinois, USA.

Chen, X., A. Viña, A. Shortridge, L. An, and J. Liu. 2014. Assessing the effectiveness of payments for ecosystem services: an agent-based modeling approach. Ecology and Society 19(1):7. https://doi.org/10.5751/ES-05578-190107

Cinner, J. E., C. Folke, T. Daw, and C. C. Hicks. 2011. Responding to change: using scenarios to understand how socioeconomic factors may influence amplifying or dampening exploitation feedbacks among Tanzanian fishers. Global Environmental Change 21(1):7-12. https://doi.org/10.1016/j.gloenvcha.2010.09.001

Colman, D., and T. Young. 1989. Principles of agricultural economics: markets and prices in less developed countries. Cambridge University Press, Cambridge, UK. https://doi. org/10.1017/CBO9780511623509

Coppock, D. L., S. Desta, S. Tezera, and G. Gebru. 2011. Capacity building helps pastoral women transform impoverished communities in Ethiopia. Science 334(6061):1394-1398. https:// doi.org/10.1126/science. 1211232

Dou, Y., P. Deadman, D. Robinson, O. Almeida, S. Rivero, N. Vogt, and M. Pinedo-Vasquez. 2017. Impacts of cash transfer programs on rural livelihoods: a case study in the Brazilian Amazon Estuary. Human Ecology 45:697-710. https://doi. org/10.1007/s10745-017-9934-1

Ellis, F. 1994. Peasant economics: farm households and agrarian development. Second edition. Cambridge University Press, Cambridge, UK.

Ellis, F. 1998. Household strategies and rural livelihood diversification. Journal of Development Studies 35(1):1-38. https:// doi.org/10.1080/00220389808422553

Ellis, F., and E. Allison. 2004. Livelihood diversification and natural resource access. Food and Agriculture Organization of the United Nations, Rome, Italy. [online] URL: http://www.fao. org/3/ad689e00.htm\#Contents

Folke, C., S. R. Carpenter, B. Walker, M. Scheffer, T. Chapin, and J. Rockström. 2010. Resilience thinking: integrating resilience, 
adaptability and transformability. Ecology and Society 15(4):20. https://doi.org/10.5751/ES-03610-150420

Folke, C., S. Carpenter, T. Elmqvist, L. Gunderson, C. S. Holling, and B. Walker. 2002. Resilience and sustainable development: building adaptive capacity in a world of transformations. Ambio 31(5):437-440. https://doi.org/10.1579/0044-7447-31.5.437

Grafton, R. Q., L. Doyen, C. Béné, E. Borgomeo, K. Brooks, L. Chu, G. S. Cumming, J. Dixon, S. Dovers, D. Garrick, A. Helfgott, Q. Jiang, P. Katic, T. Kompas, L. R. Little, N. Matthews, C. Ringler, D. Squires, S. I. Steinshamn, S. Villasante, S. Wheeler, J. Williams, and P. R. Wyrwoll. 2019. Realizing resilience for decision-making. Nature Sustainability 2(10):907-913. https:// doi.org/10.1038/s41893-019-0376-1

Grêt-Regamey, A., S. H. Huber, and R. Huber. 2019. Actors' diversity and the resilience of social-ecological systems to global change. Nature Sustainability 2(4):290-297. https://doi. org/10.1038/s41893-019-0236-Z

Hanazaki, N., F. Berkes, C. S. Seixas, and N. Peroni. 2013. Livelihood diversity, food security and resilience among the Caiçara of Coastal Brazil. Human Ecology 41(1):153-164. https:// doi.org/10.1007/s10745-012-9553-9

Holling, C. 1973. Resilience and stability of ecological systems. Annual Review of Ecology and Systematics 4:1-23. https://doi. org/10.1146/annurev.es.04.110173.000245

Huang, Q., D. C. Parker, S. Sun, and T. Filatova. 2013. Effects of agent heterogeneity in the presence of a land-market: a systematic test in an agent-based laboratory. Computers, Environment and Urban Systems 41:188-203. https://doi.org/10.1016/j.

compenvurbsys.2013.06.004

Huber, R., M. Bakker, A. Balmann, T. Berger, M. Bithell, C. Brown, A. Grêt-Regamey, H. Xiong, Q. B. Le, G. Mack, P. Meyfroidt, J. Millington, B. Müller, J. G. Polhill, Z. Sun, R. Seidl, C. Troost, and R. Finger. 2018. Representation of decisionmaking in European agricultural agent-based models. Agricultural Systems 167:143-160. https://doi.org/10.1016/j. agsy.2018.09.007

Jacobsen, S.-E. 2011. The situation for quinoa and its production in Southern Bolivia: from economic success to environmental disaster. Journal of Agronomy and Crop Science 197(5):390-399. https://doi.org/10.1111/j.1439-037X.2011.00475.X

Jean, N., M. Burke, M. Xie, W. M. Davis, D. Lobell, and S. Ermon. 2016. Combining satellite imagery and machine learning to predict poverty. Science 353(6301):790-794. https://doi. org/10.1126/science.aaf7894

Krantz, L. 2001. The sustainable livelihood approach to poverty reduction: an introduction. Swedish International Development Cooperation Agency, Stockholm, Sweden. [online] URL: https:// www.commdev.org/pdf/publications/The-Sustainable-LivelihoodApproach-to-Poverty-Reduction-SIDA.pdf

Lee, J.-S., T. Filatova, A. Ligmann-Zielinska, B. HassaniMahmooei, F. Stonedahl, I. Lorscheid, A. Voinov, G. Polhill, Z. Sun, and D. C. Parker. 2015. The complexities of agent-based modeling output analysis. Journal of Artificial Societies and Social Simulation 18(4):1-26. https://doi.org/10.18564/jasss.2897
Liu, J., T. Dietz, S. R. Carpenter, M. Alberti, C. Folke, E. Moran, A. N. Pell, P. Deadman, T. Kratz, J. Lubchenco, E. Ostrom, Z. Ouyang, W. Provencher, C. L. Redman, S. H. Schneider, and W. W. Taylor. 2007. Complexity of coupled human and natural systems. Science 317(5844):1513-1516. https://doi.org/10.1126/ science. 1144004

Mccracken, S. D., B. Boucek, and E. F. Moran. 2002. Deforestation trajectories in a frontier region of the Brazilian Amazon. Pages 215-234 in S. J. Walsh and K. A. Crews-Meyer, editors. Linking people, place, and policy: a GIScience approach. Kluwer, Boston, Massachusetts, USA. https://doi. org/10.1007/978-1-4615-0985-1 10

Malek, Ž., B. Douw, J. Van Vliet, E. H. Van Der Zanden, and P. H. Verburg. 2019. Local land-use decision-making in a global context. Environmental Research Letters (14)8. https://doi. org/10.1088/1748-9326/ab309e

National Research Council. 2005. Population, land use, and environment: research directions. National Academies Press, Washington, D.C., USA. https://doi.org/10.17226/11439

Nayak, P. K., L. E. Oliveira, and F. Berkes. 2014. Resource degradation, marginalization, and poverty in small-scale fisheries: threats to social-ecological resilience in India and Brazil. Ecology and Society 19(2):73. https://doi.org/10.5751/ES-06656-190273

Padoch, C., E. Brondizio, S. Costa, M. Pinedo-Vasquez, R. R. Sears, and A. Siqueira. 2008. Urban forest and rural cities: multisited households, consumption patterns, and forest resources in Amazonia. Ecology and Society 13(2):2. https://doi.org/10.5751/ ES-02526-130202

Pinho, P. F., J. A. Marengo, and M. S. Smith. 2015. Complex socio-ecological dynamics driven by extreme events in the Amazon. Regional Environmental Change 14(4):643-655. https:// doi.org/10.1007/s10113-014-0659-z

Rounsevell, M. D. A., D. T. Robinson, and D. Murray-Rust. 2012. From actors to agents in socio-ecological systems models. Philosophical Transactions of the Royal Society B 367 (1586):259-269. https://doi.org/10.1098/rstb.2011.0187

Smajgl, A., and E. Bohensky. 2013. Behaviour and space in agentbased modelling: poverty patterns in East Kalimantan, Indonesia. Environmental Modelling and Software 45:8-14. https://doi.org/10.1016/j.envsoft.2011.10.014

Tanner, T., D. Lewis, D. Wrathall, R. Bronen, N. Cradock-Henry, S. Huq, C. Lawless, R. Nawrotzki, V. Prasad, M. A. Rahman, R. Alaniz, K. King, K. McNamara, M. Nadiruzzaman, S. HenlyShepard, and F. Thomalla. 2015. Livelihood resilience in the face of climate change. Nature Climate Change 5(1):23-26. https://doi. org/10.1038/nclimate2431

Thomas, A.-C., and F. Gaspart. 2015. Does poverty trap rural Malagasy households? World Development 67:490-505. https:// doi.org/10.1016/j.worlddev.2014.11.012

Tittonell, P. 2014. Livelihood strategies, resilience and transformability in African agroecosystems. Agricultural Systems 126:3-14. https://doi.org/10.1016/j.agsy.2013.10.010

VanWey, L. K., Á. O. D’Antona, and E. S. Brondízio. 2007. Household demographic change and land use/land cover change 
in the Brazilian Amazon. Population and Environment 28 (3):163-185. https://doi.org/10.1007/s11111-007-0040-y

Vogt, N., M. Pinedo-Vasquez, E. S. Brondízio, F. G. Rabelo, K. Fernandes, O. Almeida, S. Riveiro, P. J. Deadman, and Y. Dou. 2016. Local ecological knowledge and incremental adaptation to changing flood patterns in the Amazon delta. Sustainability Science 11(4):611-623. https://doi.org/10.1007/s11625-015-0352-2

Vongvisouk, T., O. Mertz, S. Thongmanivong, A. Heinimann, and K. Phanvilay. 2014. Shifting cultivation stability and change: contrasting pathways of land use and livelihood change in Laos. Applied Geography 46:1-10. https://doi.org/10.1016/j.apgeog.2013.10.006

Walker, B., C. S. Holling, S. R. Carpenter, and A. Kinzig. 2004. Resilience, adaptability and transformability in social-ecological systems. Ecology and Society 9(2):5. https://doi.org/10.5751/ ES-00650-090205

Watmough, G. R., C. L. J. Marcinko, C. Sullivan, K. Tschirhart, P. K. Mutuo, C. A. Palm, and J.-C. Svenning. 2019. Socioecologically informed use of remote sensing data to predict rural household poverty. Proceedings of the National Academy of Sciences 116(4):1213-1218. https://doi.org/10.1073/pnas.1812969116

Wossen, T., and T. Berger. 2015. Climate variability, food security and poverty: agent-based assessment of policy options for farm households in Northern Ghana. Environmental Science and Policy 47:95-107. https://doi.org/10.1016/j.envsci.2014.11.009 